\title{
An arsenic-driven pump for invisible gold in hydrothermal systems
}

\author{
G.S. Pokrovski ${ }^{1 *}$, C. Escoda1, M. Blanchard1', D. Testemale², J.-L. Hazemann², \\ S. Gouy ${ }^{1}$, M.A. Kokh ${ }^{1,8}$, M.-C. Boiron ${ }^{3}$, F. de Parseval' ${ }^{1}$, T. Aigouy ${ }^{1}$, L. Menjot ${ }^{1}$, \\ P. de Parseval' ${ }^{1}$, O. Proux ${ }^{4}$, M. Rovezzi ${ }^{4}$, D. Béziat ${ }^{1}$, S. Salvi ${ }^{1}$, K. Kouzmanov ${ }^{5}$, \\ T. Bartsch ${ }^{6}$, R. Pöttgen ${ }^{6}$, T. Doert ${ }^{7}$
}

Abstract

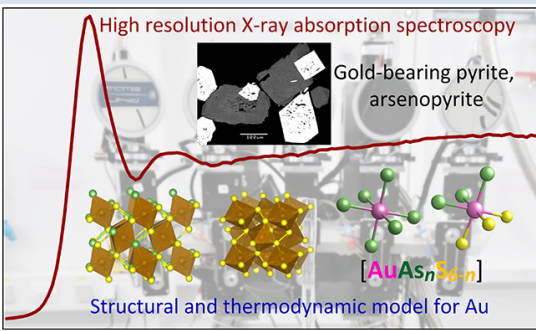

Pyrite $\left(\mathrm{FeS}_{2}\right)$, arsenopyrite (FeAsS) and löllingite $\left(\mathrm{FeAs}_{2}\right)$ are exceptional gold concentrators on Earth; yet the exact redox and structural state of this "invisible" gold and the forces driving its intake and release by these minerals remain highly controversial. Here we applied high resolution $X$-ray absorption spectroscopy to Au-bearing pyrite and iron sulfarsenides from hydrothermal deposits and their synthetic analogues. We show that Au preferentially enters octahedral Fe structural sites $\left[\mathrm{Au}(\mathrm{As}, \mathrm{S})_{6}\right]$ enriched in As, by forming respectively $\left[\mathrm{AuAs}_{1-3} \mathrm{~S}_{5-3}\right],\left[\mathrm{AuAs}_{3} \mathrm{~S}_{3} \cdots \mathrm{AuAs}_{6}\right]$ and $\left[\mathrm{AuAs}_{6}\right]$ atomic units in arsenian pyrite (>0.1-1.0 wt. \% As), arsenopyrite and löllingite, implying a formal oxidation state of $\mathrm{Au}^{\mathrm{II}}$ in the minerals. In contrast, in As-poor pyrite, $\mathrm{Au}$ is dominantly chemisorbed as $\left[\mathrm{Au}^{\mathrm{I}} \mathrm{S}_{2}\right]$ moieties in much lower concentrations. Combined with experimental data on Au mineral-fluid partitioning, our findings imply a universal control exerted by arsenic on gold incorporation in iron sulfides and sulfarsenides via coupled Au-As redox reactions. These reactions account for the observed variations in invisible gold contents in the minerals from different hydrothermal deposit types and enable quantitative prediction of iron sulfarsenide ability in controlling gold concentration and distribution in hydrothermal systems.

\section{Introduction}

Pyrite, arsenopyrite and löllingite are the key minerals in hydrothermal systems capable of concentrating gold by up to $10^{6}$ times its mean crustal and mantle abundance $(\sim 1 \mathrm{ng} / \mathrm{g})$. A large part of gold hosted by these minerals is "invisible" or "refractory" (i.e. optically undetectable) occurring both as metal nanoparticles $\left(\mathrm{Au}^{0}\right)$ and chemically bound $\mathrm{Au}$, the latter being often the dominant gold state and commonly associated with arsenic on the (sub)micron scale (e.g., Cathelineau et al., 1989; Cook and Chryssoulis, 1990; Reich et al., 2005). Thus, the redox and structural state of chemically bound Au and its link with As may define a deposit's economic potential (e.g., Kusebauch et al., 2019), determine the type and cost of Au recovery from ore (e.g., Adams, 2005) and, more generally, affect the gold distribution at the Earth's crust scale (e.g., Large et al., 2011). Despite significant advances in micro/nanoanalytical techniques over the past 20 years, the fundamental causes of the $\mathrm{Au}$-As relationship and processes that could drive gold, the most chemically inert metal of the Periodic Table, to such levels of enrichment in a host mineral yet remain enigmatic. Existing interpretations vary from the formation of aqueous $\mathrm{Au}-\mathrm{As}$ complexes or $\mathrm{Au}^{0}$ electrochemical deposition and $\mathrm{Au}(\mathrm{HS})_{2}^{-}$chemisorption on arsenian pyrite and arsenopyrite surfaces or precipitation of gold sulfide phases, to Au entering $\mathrm{Fe}$, $\mathrm{S}$ or As crystallographic sites, along with other cation substitutions or structural vacancies, and with the formal oxidation state of chemically bound Au spanning from -1 to +3 and coordination from 2 to 6 (e.g., Arehart et al., 1993; Möller and Kersten, 1994; Simon et al., 1999; Deditius et al., 2014; Pokrovski et al., 2019; Merkulova et al., 2019; Filimonova et al., 2020).

In an attempt to elucidate fundamental factors controlling the nature of invisible Au in arsenian pyrite and Fe sulfarsenides and the role played by As in Au intake, we used high energy resolution fluorescence detection $X$-ray absorption spectroscopy (HERFD-XAS), which is the most direct method to provide information about a trace element redox state, chemical bonding, and coordination at the atomic scale (e.g., Proux et al., 2017). Both X-ray absorption near-edge (XANES) and extended X-ray

\footnotetext{
Géosciences Environnement Toulouse (GET), UMR 5563 CNRS, Université Paul Sabatier Toulouse III, IRD, CNES, Observatoire Midi-Pyrénées, 14 av. Edouard Belin, F-31400 Toulouse, France

Université Grenoble Alpes, CNRS, Institut Néel, 25 av. des Martyrs, F-38042 Grenoble Cedex 9, France

Université de Lorraine, CNRS, CREGU, F-54000 Nancy, France

Université Grenoble Alpes, CNRS, IRD, Irstea, Météo France, OSUG, FAME, F-38000 Grenoble, France

University of Geneva, Department of Earth Sciences, rue des Maraîchers 13, CH-1205, Geneva, Switzerland

Institut für Anorganische und Analytische Chemie, Universität Münster, Corrensstraße 30, D-48149 Münster, Germany

Technische Universität Dresden, Faculty of Chemistry and Food Chemistry, Helmholtzstraße 10, D-01062 Dresden, Germany

Universität Potsdam, Institut für Geowissenschaften, Campus Golm, Haus 27, Karl-Liebknecht-Str. 24-25, D-14476 Potsdam, Germany

Corresponding author (email: gleb.pokrovski@get.omp.eu; glebounet@gmail.com)
} 
absorption fine structure (EXAFS) spectra were acquired on a set of thoroughly characterised $\mathrm{Au}$-bearing pyrite and arsenopyrite samples from major metamorphic and sedimentary-hosted gold deposits and their synthetic analogues (including löllingite) prepared in controlled laboratory experiments (Supplementary Information). The obtained spectroscopic and fluid-mineral partitioning data were interpreted using quantum chemistry and thermodynamic approaches to generate a new structural and physico-chemical model that reveals the fundamental role played by arsenic in gold incorporation in pyrite and $\mathrm{Fe}$ sulfarsenides.

\section{Atomic State of Gold from Spectroscopic Data}

XANES spectra of chemically bound gold in all natural and synthetic arsenopyrite, löllingite and As-rich pyrite ( $\geq 1$ wt. \% As) samples examined here significantly differ from those of metallic $\mathrm{Au}^{0}$ and other reference compounds in which $\mathrm{Au}$ is coordinated by 2 to $4 \mathrm{As} / \mathrm{S} / \mathrm{Cl}$ atoms or by $6 \mathrm{Sb} / \mathrm{Te}$ atoms, implying a different $\mathrm{Au}$ local environment in sulfarsenides (Figs. 1, S-6). In contrast, spectra of As-poor pyrites (<0.1 wt. \% As) display distinctly lower energy and amplitudes that indicate a lower Au coordination and/ or different electronic configuration than in more As-enriched samples. Quantum chemistry simulated XANES spectra of various Au positions in the mineral structure (Supplementary Information) show that $\mathrm{Au}$ enters $(\mathrm{Au}, \mathrm{Fe})(\mathrm{As}, \mathrm{S})_{6}$ octahedral sites variably enriched in As (Fig. 2). For löllingite, the measured spectra are perfectly matched by a simulated one for the $\mathrm{AuAs}_{6}$ site. For arsenopyrite, the spectra are consistent with $\mathrm{AuAs}_{3} \mathrm{~S}_{3}-\mathrm{AuAs}_{6}$ units, rather than simple Au-to-Fe substitution in a stoichiometric $\mathrm{FeAs}_{3} \mathrm{~S}_{3}$ site (Fig. S-8). These interpretations are fully supported by EXAFS analyses that yield $6 \pm 1$ As atoms at $2.53 \pm 0.01 \AA$ bound to $\mathrm{Au}$ in löllingite, and $4.5 \pm 0.5$ As at $2.51 \pm 0.02 \AA$ plus $1.5 \pm 0.5 \mathrm{~S}$ atoms at $2.42 \pm 0.05 \AA$ in arsenopyrite (Table S-4). The remarkable similarity of bound Au atomic environment among all natural and synthetic arsenopyrite samples from various geological settings and experimental conditions demonstrates the universality of the $\mathrm{Au}$ substitution mechanism. For arsenian pyrites studied here, both XANES and EXAFS data (Figs. 2, S-9) demonstrate Au to be in an As-enriched Fe site, $\mathrm{AuAs}_{3} \mathrm{~S}_{3}$. In contrast, for As-poor pyrite, spectra indicate quasi-linear $\mathrm{AuS}_{2}$ geometries, which are typical of $\mathrm{Au}^{\mathrm{I}}$ aqueous (poly)sulfide species and most thiol and sulfide solids (Pokrovski et al., 2015, 2019). The difference in Au atomic environment between As-poor pyrite on one hand and arsenian pyrite, arsenopyrite and löllingite on the other hand is strong evidence that As directly impacts the mode of Au incorporation.

\section{Structural Model for Chemically Bound Gold in Pyrite and Iron Sulfarsenides}

Our spectroscopic results combined with available data are consistent with the structural model shown in Figure 3. The degree of $\mathrm{Au}$ enrichment in pyrite generally depends on As content, being the lowest in As-poor pyrite and increasing with As content, as demonstrated by the large body of micro-to-nano scale analyses of Au and As concentrations in the mineral (Reich et al., 2005; Deditius et al., 2014), and also directly evidenced by our and recent experiments (Kusebauch et al., 2019). In As-poor pyrite, $\mathrm{Au}$ is dominantly surface-chemisorbed as $\mathrm{Au}^{\mathrm{I}}$ (poly)sulfide clusters that may be partly incorporated into structural defects and dislocations depending on crystal growth kinetics (e.g., Wu et al., 2019), and partly expulsed as $\mathrm{Au}^{0}$ nanoparticles due to the very limited capacity of pyrite to intake $\mathrm{Au}$ in the absence of As (Pokrovski et al., 2019). The pronounced change

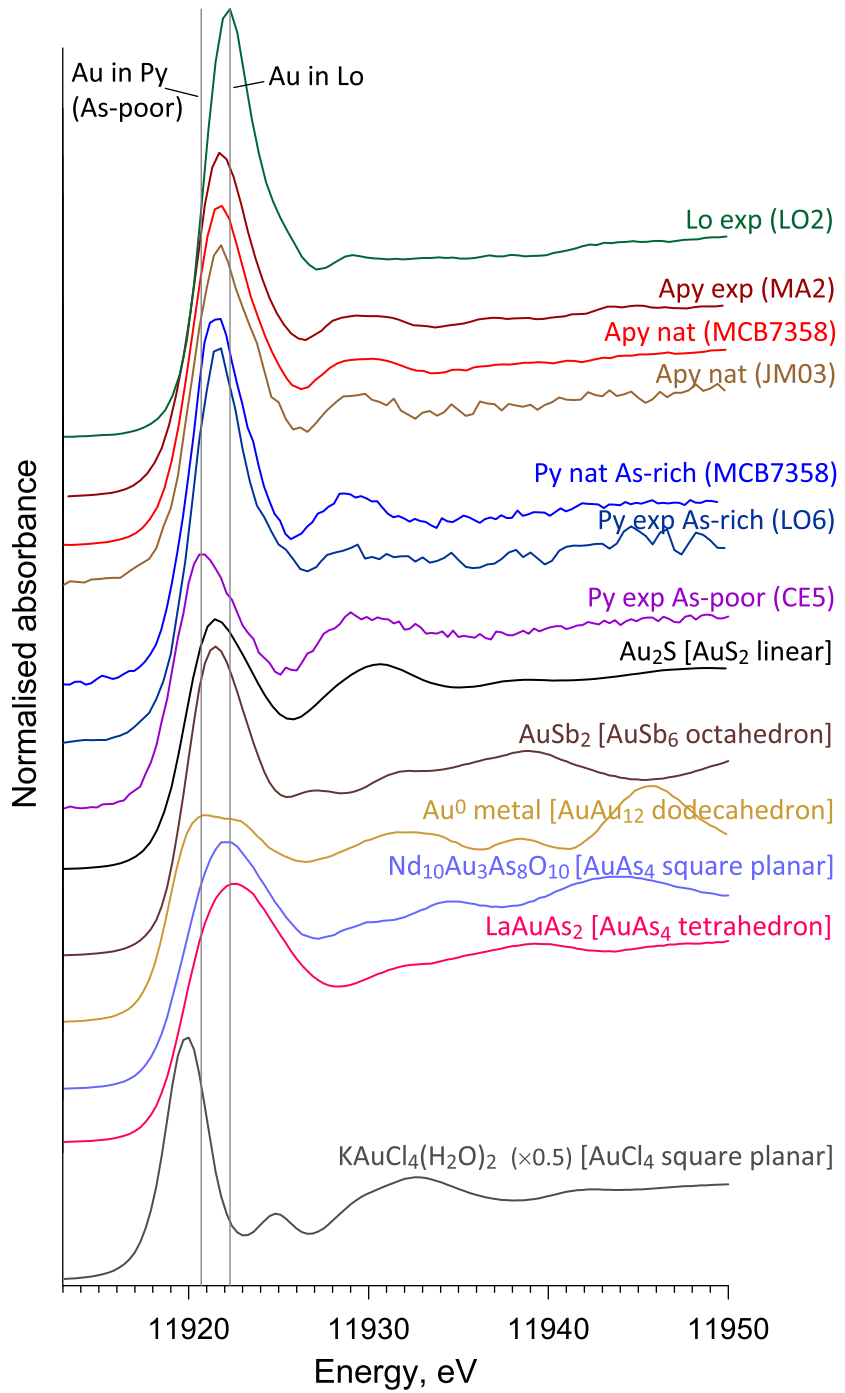

Figure 1 Gold $\mathrm{L}_{3}$-edge HERFD XANES spectra (offset vertically) of representative Au-bearing natural (nat) and experimental (exp) pyrite (Py), arsenopyrite (Apy) and löllingite (Lo) samples, and selected reference compounds with indicated Au first shell atomic coordination (see Supplementary Information for details).

in the Au solubility pattern with increasing As content above 0.01-0.1 wt. \% As (Fig. 3), as documented in many natural studies, implies a fundamental change in the gold intake mechanism to increased $\mathrm{Au}$ partitioning into As-enriched $\mathrm{Fe}(\mathrm{As}, \mathrm{S})_{6}$ sites compared to the pyrite $\mathrm{FeS}_{6}$ crystallographic site, as evidenced by the direct detection of As in the Au nearest atomic shell (Figs. 2, S-9). The number of As atoms bound to Au (n) may display large variability, from below detection limit $(n<1)$ to $n \geq 3$, as reported in recent XAS studies of some natural and synthetic pyrites with >1 wt. \% As (Merkulova et al., 2019; Filimonova et al., 2020). Thus, $A u$ in arsenian pyrite is likely to exhibit a range of $\mathrm{Au}\left(\mathrm{As}_{n} \mathrm{~S}_{6-n}\right)$ environments, from S-rich $(n \leq 1)$ to As-rich $(n \geq 3)$. This trend is followed by the continued enhancement of Au binding to As in arsenopyrite and löllingite ( $n>4$; Fig. 3). Formation of $\mathrm{Au}$ chemical bonds with $\mathrm{As}^{-\mathrm{I}}$, which is the dominant As redox state in the three minerals in most settings, provides a fundamental explanation for the systematically higher invisible Au contents analysed at the micron scale in arsenopyrite and löllingite compared to coexisting pyrite in many hydrothermal deposits (Tables S-3, S-11), as well as for experimentally measured very high $\mathrm{Au}$ partition coefficients between iron sulfarsenides and aqueous fluid ( $>10^{5}$; Table S-8). 

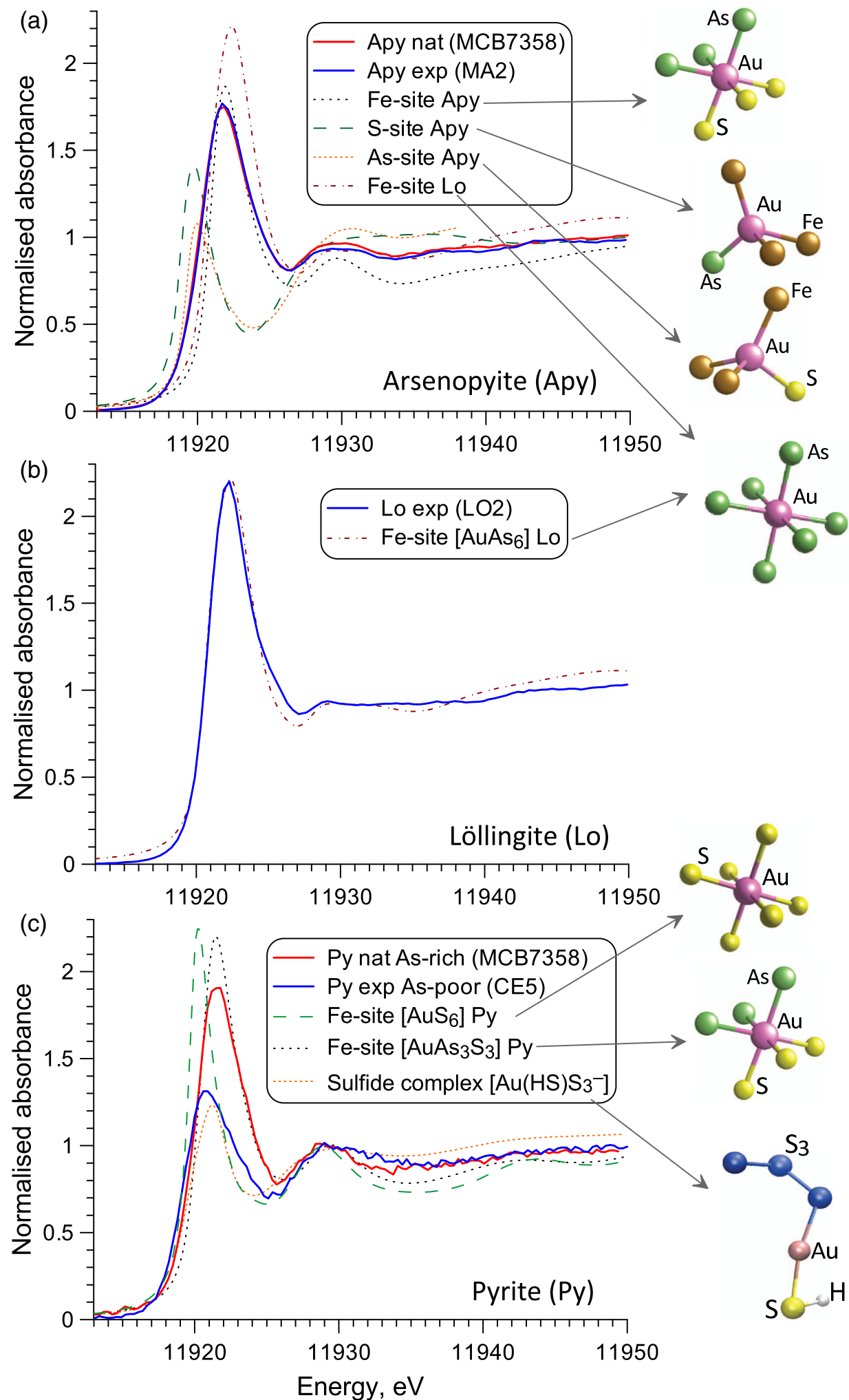

Figure 2 Comparison of $\mathrm{Au}_{3}$-edge HERFD XANES spectra of representative samples with quantum chemistry simulated spectra of Au in different structural sites as pictured by the displayed atomic clusters. The spectra of (a) Apy, (b) Lo, and (c) As-rich Py are consistent with Au in an As-enriched $\left[\mathrm{Au}\left(\mathrm{As}, \mathrm{S}_{6}\right]\right.$ octahedral site, whereas Au in As-poor Py (c) is in $\left[\mathrm{AuS}_{2}\right]$ moieties similar to those in exemplified Au'-(poly)sulfide complexes.

The available XAS data on natural pyrite and arsenopyrite samples do not reveal atoms other than As or $\mathrm{S}$ in the Au nearest shell that might accompany Au incorporation. Thus, direct $\mathrm{Au}^{\mathrm{II}}$ to $\mathrm{Fe}^{\mathrm{II}}$ substitution favoured by $\mathrm{As}^{-\mathrm{I}}$ would be a universal mechanism that does not require specific structural vacancies or charge compensations from other minor elements in different redox states $\left(\mathrm{Cu}^{\mathrm{I}}, \mathrm{Sb}{ }^{\mathrm{III}}, \mathrm{Fe}^{\mathrm{III}}, \mathrm{As}^{\mathrm{III}}\right)$. Although the notion of redox state for strongly covalent bonds such as $\mathrm{Au}-\mathrm{As}$ or $\mathrm{Au}-\mathrm{S}$ has no strict sense (Cabri et al., 2000), the formal $\mathrm{Au}^{\mathrm{II}}$ state would be consistent with the three key features of gold coordination chemistry: i) the great majority of formally $\mathrm{Au}^{\mathrm{I}}$ and $\mathrm{Au}{ }^{\mathrm{III}}$ compounds have either 2 (linear) or 4 (square/tetrahedral) $\mathrm{Au}$ coordination 


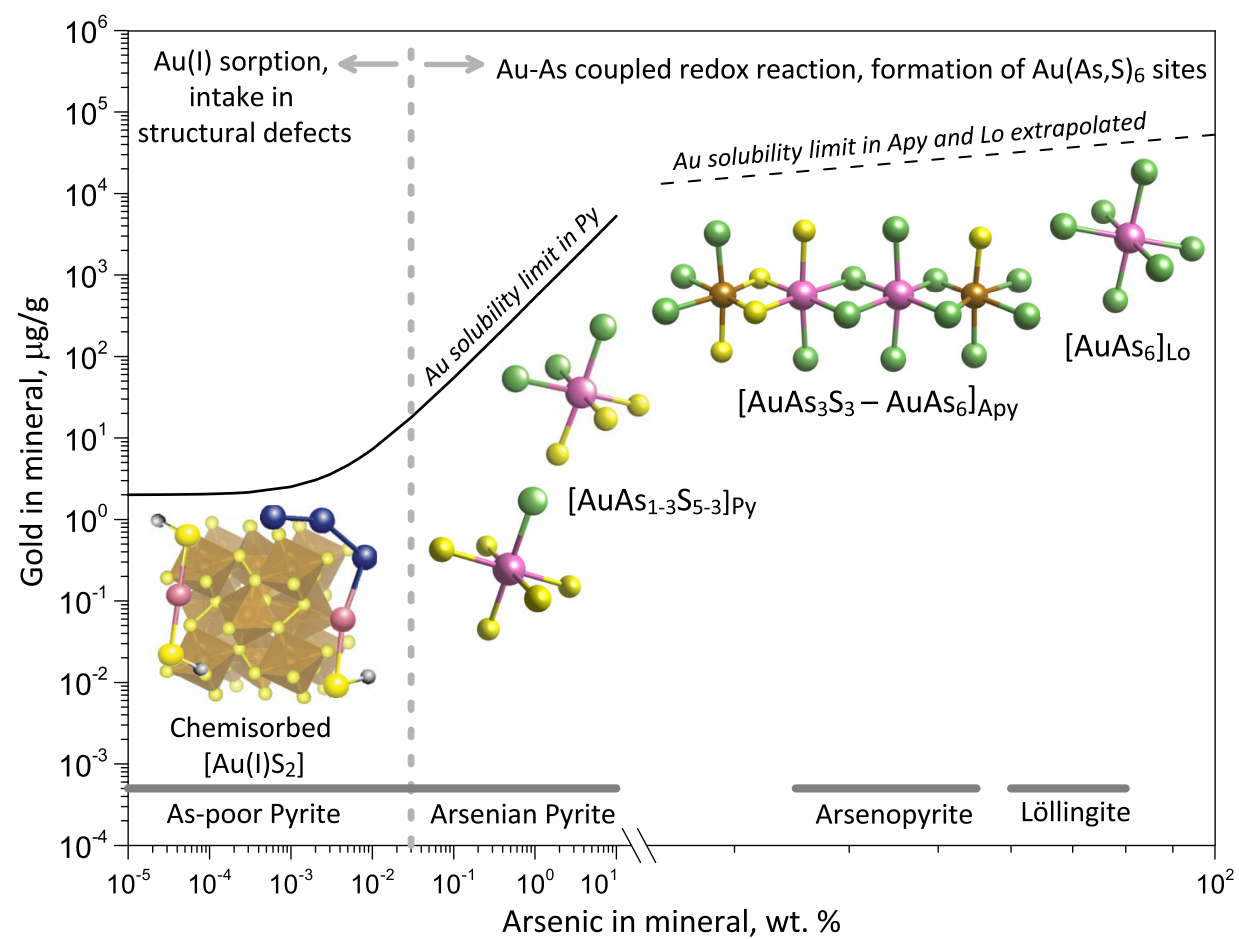

Figure 3 Structural model for chemically bound $\mathrm{Au}$ in pyrite, arsenopyrite and löllingite (not to scale). The Au coordination is shown by ball-and-stick atomic clusters ( $\mathrm{Au}=$ pink, $\mathrm{S}=$ yellow, $\mathrm{As}=$ green, $\mathrm{Fe}=$ brown, $\mathrm{S}_{3}=$ blue, $\mathrm{H}=$ grey). Horizontal gray bars indicate the typical range of As contents in each mineral. Empirical Au solubility limit in arsenian pyrite (solid curve; Reich et al., 2005) was extrapolated to Apy and Lo (dashed curve). Note a fundamental transition in the Au incorporation mechanism (vertical dashed line, indicative position), from chemisorption as Au'-polysulfide complexes at low As content in pyrite to coupled Au-As redox reactions driving Au entry in As-enriched Fe crystallographic sites of the three minerals.

(Cotton and Wilkinson, 1988) poorly compatible with an octahedral site, ii) complexes of $\mathrm{Au}^{\mathrm{II}}$ coordinated by 4 to 6 ligands $(\mathrm{S}, \mathrm{P}, \mathrm{Se})$, and often paralleled by [Au $\cdots \mathrm{Au}]$ clustering as found in arsenopyrite in this study (Fig. S-8), are well known in chemistry (Laguna and Laguna, 1999), iii) gold in many arsenide and chalcogenide compounds (AuAs $, \mathrm{AuSb}_{2}, \mathrm{AuTe}_{2}, \mathrm{AuSe}$ ) has a formal oxidation state of $\mathrm{Au}^{\mathrm{II}}$ and a coordination of 6 (ICSD, 2020). Therefore, the favourable coordination geometry coupled with redox-driven Au binding to As are the two key requirements allowing $\mathrm{Au}$ enrichment in iron sulfarsenides. These key features distinguish these minerals from other hydrothermal sulfides such as pyrrhotite, chalcopyrite, bornite, or sulfosalts that host very little invisible Au (e.g., George et al., 2017, 2018).

\section{Thermodynamic Model for Gold Solubility in Arsenopyrite and Löllingite}

Gold incorporation in iron sulfarsenides may thus be interpreted as a coupled redox reaction between the dominant $\mathrm{Au}^{\mathrm{I}} / \mathrm{As}^{\mathrm{III}}$ redox states in the hydrothermal fluid and $\mathrm{Au}^{\mathrm{II}} / \mathrm{As}^{-\mathrm{I}}$ in the mineral. Because $\mathrm{Au}$ in arsenopyrite occurs in a combination of arsenopyrite and löllingite-type sites (Fig. 3), Au solubility and partitioning may be formally approximated by a hypothetical sulfarsenide end member AuAsS-AuAs 2 (equivalent to $\mathrm{AuAs}_{1.5} \mathrm{~S}_{0.5}$ ) "dissolved" in arsenopyrite:

$$
\begin{aligned}
& \mathrm{Au}(\mathrm{HS})_{2}^{-}+\mathrm{H}^{+}+1.5 \mathrm{As}(\mathrm{OH})_{3} \\
& =\left[\mathrm{AuAs}_{1.5} \mathrm{~S}_{0.5}\right]_{\text {Apy }}+1.125 \mathrm{O}_{2}+1.5 \mathrm{H}_{2} \mathrm{~S}+2.25 \mathrm{H}_{2} \mathrm{O} \\
& \mathrm{Au}^{0}(\text { metal })+1.5 \mathrm{As}(\mathrm{OH})_{3}+0.5 \mathrm{H}_{2} \mathrm{~S} \\
& =\left[\mathrm{AuAs}_{1.5} \mathrm{~S}_{0.5}\right]_{\text {Apy }}+0.875 \mathrm{O}_{2}+2.75 \mathrm{H}_{2} \mathrm{O}
\end{aligned}
$$

where $\left[\mathrm{AuAs}{ }_{1.5} \mathrm{~S}_{0.5}\right]_{\text {Apy }}$ is the mole fraction of the $\mathrm{Au}$-sulfarsenide end member in the arsenopyrite solid solution, and $\mathrm{Au}(\mathrm{HS})_{2}^{-}$and $\mathrm{As}(\mathrm{OH})_{3}$ are the activities of the major $\mathrm{Au}$ and As aqueous species in the fluid (Perfetti et al., 2008; Pokrovski et al., 2015). The thermodynamic constants of reactions (Eq. 1) and (Eq. 2), derived from experimental mineral-fluid partition coefficients at $450{ }^{\circ} \mathrm{C}$ and 700 bar are $\log _{10} K_{1}=-18.2 \pm 0.3$ and $\log _{10} K_{2}=-22.4 \pm 0.3$, respectively (1 s.d.; Table S-9). An analogous model of the $\mathrm{AuAs}_{2}-\mathrm{FeAs}_{2}$ solid solution is valid for löllingite (Table S-10). The generated constants enable, for the first time, direct predictions of Au mineral-fluid partitioning and solubility in sulfarsenides as a function of the key hydrothermal fluid parameters such as As/S content, redox and pH (Fig. 4). Applying similar quantitative models to pyrite would require more systematic experimental and natural data to account for the large range in the $\mathrm{Au}\left(\mathrm{As}_{n} \mathrm{~S}_{6-n}\right)$ site stoichiometry (Fig. 3). The empirical gold solubility limit reported for arsenian pyrite is likely to be defined by reactions analogous to (Eq. 1) and (Eq. 2), thereby reflecting the natural variability limits of the fluid parameters.

\section{Implications}

Our new findings help to clarify one of the oldest enigmas of geochemistry about the unique role played by arsenic in Au fate in hydrothermal systems. Our results demonstrate that both arsenopyrite and löllingite are capable of accommodating large concentrations of bound $\mathrm{Au}(100 \mathrm{~s}$ to $1000 \mathrm{~s} \mu \mathrm{g} / \mathrm{g}$ ) even from $\mathrm{Au}$-poor fluids $(<0.1 \mu \mathrm{g} / \mathrm{g} \mathrm{Au})$ in relatively reduced metamorphic and ultramafic rock settings $\left(f_{\mathrm{O} 2}<\mathrm{NNO}\right.$; Fig. $\left.4 \mathrm{a}\right)$, whereas in more oxidised orogenic- and porphyry-related systems little $\mathrm{Au}$ is incorporated, in full agreement with natural observations (e.g., Deditius et al., 2014). Our quantitative predictions are currently limited at $450{ }^{\circ} \mathrm{C}$, but lower temperatures may further 
(a) Ni-PGE-bearing Orogenic Au Porphyry $\mathrm{Cu}(-\mathrm{Mo}-\mathrm{Au})$

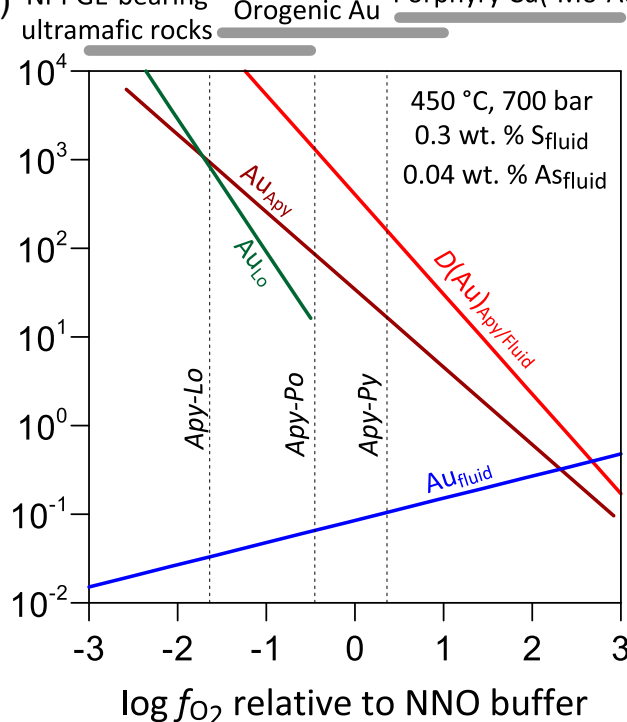

(b) $\quad \because \cdots-$ W Africa, Red Lake, Sunrise, Urals

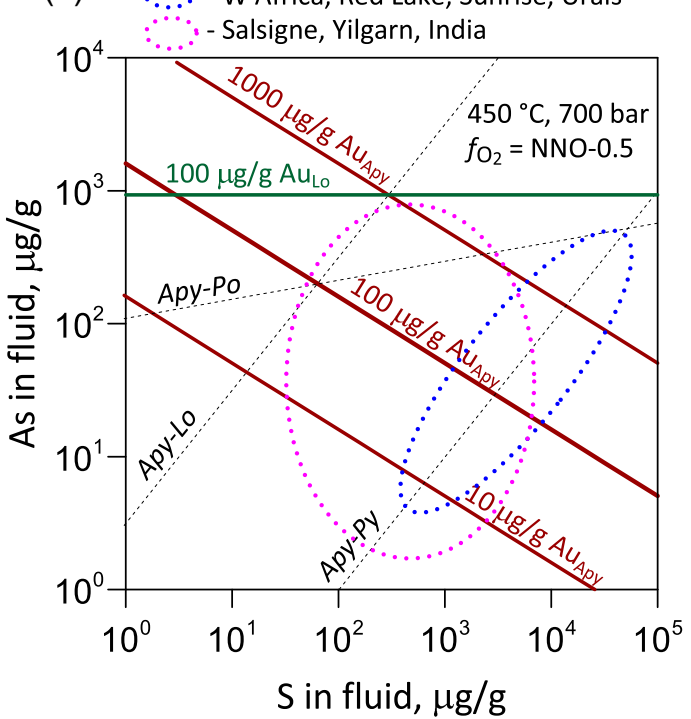

Figure 4 Gold solubility in arsenopyrite (Apy) and löllingite (Lo) in equilibrium with hydrothermal fluid and native gold, predicted as a function of (a) $\log f_{\mathrm{O} 2}$ (in bars, relative to the nickel-nickel oxide $\mathrm{O}_{2}$ buffer, NNO) at typical $\mathrm{H}_{2} \mathrm{~S}$ and $\mathrm{As}(\mathrm{OH})_{3}$ fluid phase concentrations for the indicated major types of gold deposits, and (b) As and S fluid phase content at $f_{\mathrm{O} 2}$ of NNO-0.5 within the Apy stability domain (Perfetti et al., 2008) in metamorphic gold deposits (circles; Table S-11 for compilation). Also plotted are equilibrium $\mathrm{Au}(\mathrm{HS}) \overline{2}$ concentrations in fluid (blue curve), Au Apy/Fluid partition coefficient ( $D(\mathrm{Au})_{\text {Apy/Fluid, }}$ mass units ratio, same y scale, red curve), and Apy-Lo, Apy-pyrrhotite (Po), and Apy-pyrite (Py) equilibrium lines.

favour $\mathrm{Au}-\mathrm{As}$ redox reactions and $\mathrm{Au}$ intake in sulfarsenides, consistent with enhanced equilibrium As partitioning into pyrite (Xing et al., 2019). Surface sorption and mineral growth rate factors may also contribute to Au scavenging (e.g., Wu et al., 2019), but the fundamental arsenic-driven redox control will equally hold. Changes in redox, $\mathrm{pH}$ and dissolved As/S contents upon fluid evolution adequately account for the large variability of Au content widely documented in different mineral generations within individual deposits and across mineralised domains in different deposit types (Fig. 4b). Gold intake by and release from sulfarsenides driven by variations in fluid composition appear to be key factors for hydrothermal gold deposit formation. For example, in giant Carlin-type deposits, these factors may have driven focused coupled Au and As-pyrite deposition (Kusebauch et al., 2019). In orogenic-type deposits, first order Au "pumping" from the fluid by pyrite and arsenopyrite, followed by large scale $\mathrm{Au}$ liberation from those minerals during further metamorphism, may have provided a gold source and strongly influenced metal endowment, timing of mineralisation, and spatial distribution (Large et al., 2011; Velásquez et al., 2014; Fougerouse et al., 2016). Future advances of in situ spectroscopy will offer more systematic quantification of invisible gold along with other valuable trace metals hidden in iron sulfarsenide minerals, thereby enabling a better understanding of trace element geochemical cycles and improving resource assessment, exploration and recovery.

\section{Acknowledgments}

This work was funded by the French National Research Agency (RadicalS ANR-16-CE31-0017, SOUMET ANR-2011-BlancSIMI-5-6-009), the Institut des Sciences de l'Univers of the Centre National de la Recherche Scientifique, INSU-CNRS (CESSUR-OrPy-AsOrPy), the Institut Carnot ISIFoR (OrPet), and the West African Exploration Initiative (WAXI-P934A). We acknowledge the European Synchrotron Radiation Facility (ESRF) for providing access to beam time and infrastructure, and AMIRA International for support in field-related aspects. The FAME-UHD project is supported by the French Grand Emprunt EquipEx (EcoX ANR-10-EQPX-27-01), the CEA-CNRS CRG consortium and the INSU-CNRS. DFT calculations were performed using HPC resources from CALMIP (2020-P1037). We thank A.-M. Cousin for invaluable help with figure layout, S. Foulon for tube welding, A. Manceau and B. Tagirov for sharing XAS data and references, and Y. Joly for advice on XANES modeling. Comments by Editor S. Redfern and an anonymous referee greatly improved this article.

Editor: Simon Redfern

\section{Additional Information}

Supplementary Information accompanies this letter at https:// www.geochemicalperspectivesletters.org/article2112.

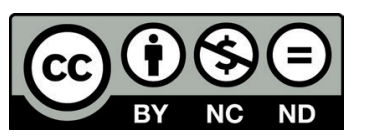

(C) 2021 The Authors. This work is distributed under the Creative Commons Attribution NonCommercial No-Derivatives 4.0 License, which permits unrestricted distribution provided the original author and source are credited. The material may not be adapted (remixed, transformed or built upon) or used for commercial purposes without written permission from the author. Additional information is available at https://www. geochemicalperspectivesletters.org/copyright-and-permissions.

Cite this letter as: Pokrovski, G.S., Escoda, C., Blanchard, M., Testemale, D., Hazemann, J.-L., Gouy, S., Kokh, M.A., Boiron, M.-C., de Parseval, F., Aigouy, T., Menjot, L., de Parseval, P., Proux, O., Rovezzi, M., Béziat, D., Salvi, S., Kouzmanov, K., Bartsch, T., Pöttgen, R., Doert, T. (2021) An arsenic-driven pump for invisible gold in hydrothermal systems. Geochem. Persp. Let. 17, 39-44. 


\section{References}

AdAms, M.D. (Ed.) (2005) Advances in Gold Ore Processing. Elsevier Science, Amsterdam.

Arehart, G.B., Chryssoulis, S.L., Kesler, S.E. (1993) Gold and arsenic in iron sulfides from sediment-hosted disseminated gold deposits: Implication for depositional processes. Economic Geology 88, 171-185.

Cabri, L.J., Newville, M., Gordon, R.A., Crozier, E.D., Sutton, S.R., McMahon, G. JIANG, D.-T. (2000) Chemical speciation of gold in arsenopyrite. Canadian Mineralogist 38, 1265-1281.

Cathelineau, M., Boiron, M.-C., Holliger, P., Marion, P., Denis, M. (1989) Gold in arsenopyrites: Crystal chemistry, location and state, physical and chemical conditions of deposition. Economic Geology Monograph 6, 328-341.

Cook, N.J., Chryssoulis, S.L. (1990) Concentrations of "invisible" gold in the common sulfides. Canadian Mineralogist 28, 1-16.

Cotton, A.F., Wilkinson, G. (1988) Advanced Inorganic Chemistry. Fifth Edition, Wiley, New York.

Deditius, A.P., Reich, M., Kesler, S.E, Utsunomiya, S, Walshe, J., Chryssoulis, S.L., EwING, R.C. (2014) The coupled geochemistry of Au and As in pyrite from hydrothermal deposits. Geochimica et Cosmochimica Acta 140, 644-670.

Filimonova, O.N., TAgirov, B.R., Trigub, A.L., Nickolsky, M.S., Rovezzi, M., Belogub, E.V., Reukov, V.L., Vikentiev, I.A. (2020) The state of $\mathrm{Au}$ and As in pyrite studied by $\mathrm{X}$-ray absorption spectroscopy of natural mineral and synthetic phases. Ore Geology Reviews 121, 103475.

Fougerouse, D, Micklethwatte, S, Tomkins, A.G, Mei, $Y$, Kilburn, M Guagliardo, P., Fisher, L.A., Halfpenny, A., Gee, M., Paterson, D., HowARD, D.L. (2016) Gold remobilisation and formation of high grade ore shoots driven by dissolution-reprecipitation replacement and $\mathrm{Ni}$ substitution into auriferous arsenopyrite. Geochimica et Cosmochimica Acta 178, 143-159.

George, L.L., CooK, N.J., Ciobanu, C.L. (2017) Minor and trace elements in natura tetrahedrite-tennantite: Effects of element partitioning among base metal sulphides. Minerals 7, 17

George, L.L., Cook, N.J., Crowe, B.B.P., Ciobanu, C.L. (2018) Trace elements in hydrothermal chalcopyrite. Mineralogical Magazine 82, 59-88.

ICSD (2020) Inorganic Crystal Structure Database. ICSD, FIZ Karlsruhe. https://icsd. products.fiz-karlsruhe.de, accessed 2 April 2021.

Kusebauch, C., Gleeson, S.A., Oelze, M. (2019) Coupled partitioning of Au and As into pyrite controls the formation of giant Au deposits. Science Advances 5 , eaav5891.

Laguna, A., Laguna, M. (1999) Coordination chemistry of gold(II) complexes. Coordination Chemistry Reviews 193-195, 837-856.

Large, R.R., Bull, S.W., Maslennikov, V.V. (2011) A carbonaceous sedimentary source-rock model for Carlin-type and orogenic gold deposits. Economic Geology 106, 331-358.

Merkulova, M. Mathon, O Giatzel, P, Rovezzi, M., Batanova, V., Marion, P. BOIRON, M.-C., MANCEAU, A. (2019) Revealing the chemical form of "invisible" gold in natural arsenian pyrite and arsenopyrite with high energyresolution X-ray absorption spectroscopy: ACS Earth Space Chemistry 3, 1905-1914.

MölleR, P., Kersten, G. (1994) Electrochemical accumulation of visible gold on pyrite and arsenopyrite surfaces. Mineralium Deposita 29, 404-413.

Perfetti, E., Pokroviski, G.S., Ballerat-Busserolles, K., Majer, V., Gibert, F. (2008) Densities and heat capacities of aqueous arsenious and arsenic acid solutions to $350{ }^{\circ} \mathrm{C}$ and $300 \mathrm{bar}$, and revised thermodynamic properties of $\mathrm{As}(\mathrm{OH})_{3}{ }^{0}(\mathrm{aq}), \mathrm{AsO}(\mathrm{OH})_{3}{ }^{0}(\mathrm{aq})$ and iron sulfarsenide minerals. Geochimica et Cosmochimica Acta 72, 713-731.

Pokrovski, G.S. КокH, M.A. Guillaume, D. Borisova, A.Y., Gisouet, P. Hazemann, J.-L., Lahera, E., Del Net, W., Proux, O., Testemale, D. Haigis, V., Jonchière, R., Seitsonen, A.P., Ferlat, G., Vuilleumier, R. SAITTA, A.M., Boiron, M.-C., Dubessy, J. (2015) Sulfur radical species form gold deposits on Earth. Proceedings of the National Academy of Sciences 112, 13484-13489.

Pokrovski, G.S., Kokh, M.A., Proux, O., Hazemann, J.-L., Bazarkina, E.F. Testemale, D., Escoda, C., Boiron, M.-C., Blanchard, M., Ajgouy, T. Gouy, S., De Parseval, P., Thibaut, M. (2019) The nature and partitioning of invisible gold in the pyrite-fluid system. Ore Geology Reviews 109, $545-563$.

Proux, O., Lahera, E., Del Net, W., Kieffer, I., Rovezzi, M., Testemale, D., Irar, M. Thomas, S., Agullar-Tapia, A., Bazarkina, E.F., Prat, A., Tella, M. Auffan, M., Rose, J., Hazemann, J.-L. (2017) High energy resolution fluorescence detected X-ray absorption spectroscopy: a new powerful structural tool in environmental biogeochemistry sciences. Journal of Environmental Quality 46, 1146-1157.
Reich, M., Kesler, S.E., Utsunomiya, S., Palenik, C.S., Chryssoulis, S.L., Ewing, R.C. $(2005)$ Solubility of gold in arsenian pyrite. Geochimica et Cosmochimica Acta $69,2781-2796$

Simon, G., Huang, H., Penner-Hahn, J.E., Kesler, S.E., KaO, L.-S. (1999) Oxidation state of gold and arsenic in gold-bearing arsenian pyrite. American Mineralogist 84, 1071-1079.

Velásquez, G., Béziat, D., Salvi, S., Siebenaller, L., Borisova, A.Y., Pokrovski, G.S., DE PARSEVAL, P. (2014) Formation and deformation of pyrite and implications for gold mineralization at the El Callao mining district, Venezuela. Economic Geology 109, 457-486.

Wu, Y.-F., Fougerouse, D., Evans, K., Reddy, S.M., SaXey, D.W., Guagliardo, P., LI, J.-W. (2019) Gold, arsenic, and copper zoning in pyrite: A record of fluid chemistry and growth kinetics. Geology 47, 641-644.

XING, Y., BRUgGer, J., TomkINS, A., SHVARov, Y.V. (2019) Arsenic evolution as a tool for understanding formation of pyritic gold ores. Geology 47, 335-338. 